\title{
Exaggerated Triglyceride Accretion in Human Preadipocyte-Murine Renal Line Hybrids Composed of Cells from Massively Obese Subjects
}

\author{
Paul E. Le Blanc, Daniel A. K. Roncari, David I. Hoar, and Anne-Marie Adachi \\ Departments of Medicine, Medical Biochemistry, Paediatrics, and Julia McFarlane Diabetes Research Unit, The University of Calgary, \\ Calgary, Alberta, Canada T2N 4N1, and Foothills Hospital, Calgary, Canada T2N 2T9
}

\begin{abstract}
To learn about adipose differentiation of precursors from postnatal adipose tissue of lean and massively obese subjects, human omental adipocyte precursor-murine renal adenocarcinoma cell (RAG) hybrids were formed by fusion with polyethylene glycol, and cultured selectively with $50 \mu \mathrm{M}$ ouabain in hypoxanthine aminopterin thymidine (HAT) medium. Under conditions in which the parent cells did not differentiate, a number of hybrids, which were cloned, revealed morphologic and biochemical evidence of differentiation. In addition to activation of human genes within the common nucleus of the hybrids, murine cytoplasmic activators are probably also involved because heterocaryons (fused cells with two interspecific nuclei) revealed the same phenomenon. Hybrids composed of precursors from massively obese subjects disclosed more frequent and prominent differentiation. Since these hybrids, in contrast to those from the lean, recapitulate this phenomenon in subcultures, they provide the potential system for mapping the human gene(s) responsible for adipose differentiation and its exaggeration in massive obesity.
\end{abstract}

\section{Introduction}

The process of adipose differentiation features the conversion of motile, fibroblast-like cells, termed adipocyte precursors, to relatively immobile, round, triglyceride-laden adipocytes (1). While this process has been studied in such model systems as cultured (fetal) murine 3T3 sublines susceptible to adipose conversion $(2,3)$, the mechanisms mediating the maturation of fat cells in postnatal adipose tissue are not known. Thus also unexplained is the unusual susceptibility of some adipocyte precursor clones from massively obese persons, to differentiate in culture (4).

To gain insight into the process of adipose differentiation, including the possible localization of the gene(s) responsible for this process or for the apparently inordinate differentiation of some precursor clones in human massive obesity, we have prepared human adipocyte precursor-murine renal adenocar-

Part of this research was presented at the Annual Meeting of the Canadian Society for Clinical Investigation, September 1985, Vancouver, Canada.

Address reprint requests to Dr. Roncari, Department of Medicine, Sunnybrook Medical Centre-University of Toronto, 2075 Bayview Ave., Toronto, ON, Canada M4N 3M5.

Received for publication 18 September 1986 and in revised form 29 October 1987.

J. Clin. Invest.

(c) The American Society for Clinical Investigation, Inc.

0021-9738/88/05/1639/07 \$2.00

Volume 81, May 1988, 1639-1645 cinoma cell (RAG) ${ }^{1}$ hybrids composed of precursors from either lean or massively obese subjects. As described in this paper, these hybrids have revealed unusual properties.

\section{Methods}

Cell culture and fusion. Adipocyte precursors were isolated from omental adipose tissue of lean and massively obese ( $>170 \%$ of reference body wt) subjects at elective abdominal surgery, and cultured as previously reported (4-6). The RAG cell line (originally established from a mouse renal adenocarcinoma clone) was a generous gift of Dr. C. C. Lin, now at the University of Alberta, Edmonton, Alberta (7). Adipocyte precursors $\left(7.5 \times 10^{5}\right.$, in first subculture) from three lean and four obese subjects, were fused, each cell strain separately, with RAG cells $\left(1.5 \times 10^{6}\right)$ by mixing $0.5 \mathrm{ml}$ of the cells partially resuspended in HBSS (Gibco Laboratories, Grand Island, NY), with $0.5 \mathrm{ml}$ of a $50 \%$ solution of polyethylene glycol $\left(M_{\mathrm{r}} 8,000\right.$; Eastman Kodak Co., Rochester, NY) at $37^{\circ} \mathrm{C}$ for $1 \mathrm{~min}$. The suspension was then diluted by adding HBSS solution to a total of $30 \mathrm{ml}$ over a period of 5 $\min$. The diluted suspension was centrifuged at $800 \mathrm{~g}$ for $10 \mathrm{~min}$ with the resulting pellet being resuspended and grown for $14 \mathrm{~h}$ in complete Alpha Medium (Gibco Laboratories), supplemented with 15\% (vol/ vol) fetal bovine serum (Flow Laboratories, McLean, VA), penicillin $(100 \mathrm{U} / \mathrm{ml})$ and streptomycin $(100 \mu \mathrm{g} / \mathrm{ml})$, to promote adherence to 75- $\mathrm{cm}^{2}$ flasks (Becton Dickinson and Co., Oxnard, CA) $(7,8)$. The medium was then changed to include $100 \mu \mathrm{M}$ hypoxanthine, $0.4 \mu \mathrm{M}$ aminopterin, and $16 \mu \mathrm{M}$ thymidine (HAT) (Sigma Chemical Co., St. Louis, MO) to select against unfused RAG cells (HPRT ${ }^{-}$), or RAGRAG fusion products, and $50 \mu \mathrm{M}$ ouabain (Sigma Chemical Co.) to select against unfused human adipocyte precursors, and precursorprecursor fusion products $(9,10)$. Control studies, designed to address whether unfused human and/or murine cells were present in the mixed (i.e., uncloned) hybrid cell populations, were performed. Separate cultures of human precursors treated with ouabain resulted in the death of all cells within 6-7 d, while separate cultures of murine (RAG) cells treated with HAT medium resulted in the death of all cells within 5-6 d. By the same procedures, cell hybrids were formed by fusing human skin fibroblasts (cell line CRL 1221, American Type Culture Collection, Rockville, MD) to the murine renal (RAG) cell line. In all cases, the culture medium was changed every 3-4 d. For comparative purposes, adipocyte precursors (obese with obese and lean with obese) were fused with each other, as were RAG cells, and cultured without selection. In the case of all cell types, observations were made by phase contrast light microscopy, and staining with Oil-Red-O (5). In preadipose cells, neutral lipid accumulation revealed by such staining is a reliable indicator of triglyceride accretion and adipose differentiation (11). In any case, determination of triglyceride content and enzyme assays were used for confirmation, as will be described.

Subculture and cloning of cell hybrids. For these studies, the already described selective culture medium was used, except that the concentration of fetal bovine serum was decreased to $10 \%$. After culturing the possible products of fusion between adipocyte precursors and RAG

1. Abbreviations used in this paper: HAT, hypoxanthine, aminopterin, thymidine; RAG, renal adenocarcinoma line. 
cells for $21 \mathrm{~d}$, cloning cylinders were placed over the candidate colonies, which were detached with $0.5 \mathrm{mg} / \mathrm{ml}$ trypsin $-0.2 \mathrm{mg} / \mathrm{ml}$ $\mathrm{Na}_{2}$ EDTA (Gibco Laboratories). The released cells were transferred to $25-$ or $75-\mathrm{cm}^{2}$ flasks. After $14 \mathrm{~d}$ of culture, the cells were detached with trypsin-EDTA, diluted to a calculated ratio of 0.3 cells/well, and seeded in 96-well plates (Costar Data Packaging Corp., Cambridge, MA). Only cells in wells revealing a single colony were used for further studies of cell clones.

Molecular hybridization. To confirm the presence of interspecific cell hybrids, DNA was extracted from $\sim 10^{6}$ hybrid cells, from a mixed population, and about the same number of human adipocyte precursors, and of RAG cells (12). The DNA was obtained from all cell types at the stage of active multiplication, well before monolayer confluence. Eco RI digests of $2 \mu \mathrm{g}$ DNA were separated on $1 \%$ agarose gels and blotted by capillary under alkaline conditions to a Zeta-Probe membrane (Bio-Rad Laboratories, Richmond, $\mathrm{CA}$ ) using $0.4 \mathrm{~N} \mathrm{NaOH}$ as the transfer medium. The restriction fragments were first hybridized with a human, low copy repeat fragment (phMF-1, $1 \times 10^{9} \mathrm{cpm} / \mu \mathrm{g}$ ) (13), washed, and rehybridized with the Bam HI fragment of mouse mitochondrial DNA (pmMt, $9 \times 10^{8} \mathrm{cpm} / \mu \mathrm{g}$ ) (cloned by D. I. Hoar, The University of Calgary, Calgary, Alberta), using a hybridization mixture of $0.4 \mathrm{M}$ sodium phosphate, $\mathrm{pH} 6.5,5 \%$ SDS, $10 \mathrm{mM}$ EDTA, $10 \mathrm{mg} / \mathrm{ml}$ bovine serum albumin, $0.3 \mathrm{mg} / \mathrm{ml}$ yeast RNA, and $30 \%$ (vol/vol) formamide at $43^{\circ} \mathrm{C}$. The probes were labeled with ${ }^{32} \mathrm{P}$ according to reported methods $(14,15)$. All washes were with a solution containing $30 \mathrm{mM}$ sodium chloride, $3 \mathrm{mM}$ sodium citrate, $\mathrm{pH} 7.0$, $0.5 \%$ SDS at $43^{\circ} \mathrm{C}$. The autoradiographic exposures were for $14 \mathrm{~h}$ for the human probe and $4 \mathrm{~h}$ for the mouse mitochondrial probe (12).

Promotion of adipose differentiation. After growing the hybrids to confluence in selective medium, $0.5 \mathrm{mM} 1$-methyl-3-isobutyl-xanthine and $0.25 \mu \mathrm{M}$ dexamethasone (Sigma Chemical Co.) were added and incubated for $72 \mathrm{~h}(16)$. The medium was then replaced for three more days with complete Alpha Medium supplemented with $20 \%$ fetal bovine serum and $5 \mu \mathrm{g} / \mathrm{ml}$ bovine insulin (Gibco Laboratories).

Glyceride-glycerol determination. Adipocyte precursors and the various hybrid cells were washed three times with HBSS, each time centrifuging the suspension at $800 \mathrm{~g}$ for $10 \mathrm{~min}$. Finally, the cells were resuspended in distilled, deionized ("nanopure") water, sonicated 3 $\times 30 \mathrm{~s}$, and the resulting suspension was centrifuged at $48,000 \mathrm{~g}$ for 30 $\min$ at $4^{\circ} \mathrm{C}$. Aliquots of supernate were then treated with 5 vol of $0.5 \mathrm{M}$ $\mathrm{KOH}$ in ethanol at $70^{\circ} \mathrm{C}$ for $30 \mathrm{~min}$ by a reported method (17). After neutralization with $2.5 \mathrm{M} \mathrm{HCl}$, and evaporation of the ethanol under $\mathrm{N}_{2}$ gas, aliquots were assayed for glycerol using three linked enzymatic steps and quantifying the consumption of NADH at $340 \mathrm{~nm}$ with a spectrophotometer (Response TM; Gilford Instrument Laboratories, Oberlin, $\mathrm{OH}$ ) (17). Using water as a blank, standard curves for glycerol (derived from Sigma Lipid Control-E) were linear at the tested range of 1 to $10 \mu \mathrm{g}$. Protein concentration was determined by the Bio-Rad method (Bio-Rad Laboratories), with bovine serum albumin as standard.

Glycerophosphate dehydrogenase assay. Cells were washed with HBSS and detached, using a cell scraper, into the same solution. The suspension was centrifuged at $800 \mathrm{~g}$ for $10 \mathrm{~min}$, and the resulting pellet was resuspended in a minimal volume of a $50 \mathrm{mM}$ Tris buffer ( $\mathrm{pH} 7.5$ ) containing $0.25 \mathrm{M}$ sucrose and $1 \mathrm{mM} \mathrm{Na}{ }_{2}$ EDTA. This suspension was sonicated $3 \times 30 \mathrm{~s}$ and centrifuged at $48,000 \mathrm{~g}$ for $1 \mathrm{~h}$ at $4^{\circ} \mathrm{C}$ to yield the supernatant that was used to determine glycerophosphate dehydrogenase (E.C.1.1.1.8) activity, basically as reported (18). The final volume of the assay mixture was $200 \mu \mathrm{l}$ containing $10-100 \mu \mathrm{g}$ of protein. Assays were conducted in duplicate or triplicate at saturating concentrations of substrates and cosubstrates under linear conditions at three levels of enzyme preparation protein, with the spectrophotometer. One unit of enzyme activity is defined as the dihydroxyacetone phosphate-dependent oxidation of $1 \mathrm{nmol} \mathrm{NADH}$ per min at $27^{\circ} \mathrm{C}$. To obtain an indication of the isoenzyme pattern of the glycerophosphate dehydrogenase that was expressed, extracts were incubated at $50^{\circ} \mathrm{C}$ for various periods before assay (18).

\section{Results}

Molecular hybridization. As indicated by the open arrow pointing to the left autoradiogram in Fig. 1, the [ $\left.{ }^{32} \mathrm{P}\right] \mathrm{DNA}$ probe specific for human DNA, hybridized with DNA of fusion products composed of adipocyte precursors from the massively obese $(A)$, those comprised of precursors from the lean $(B)$, and DNA of unfused precursors from the obese $(C)$, but corresponding hybridization did not occur with DNA of unfused RAG cells $(D)$. As indicated by the solid arrow pointing to the right autoradiogram in Fig. 1, the probe specific for murine DNA hybridized with DNA of both types of fusion products $\left(A^{\prime}, B^{\prime}\right)$ and of course with the unfused RAG cells (D'), but corresponding hybridization did not occur with unfused adipocyte precursors $\left(\mathrm{C}^{\prime}\right)$.

Morphology of hybrid cells. The mixed (i.e., those that were not cloned) population of human adipocyte precursor-murine RAG hybrids was heterogeneous in terms of morphologic expression (Fig. $2 A, B$ ). Three general types of fused cells were observed: relatively large, round cells revealing accumulation of neutral lipid (triglyceride), as indicated by Oil-Red-O, similar cells but devoid of staining material, and fibroblast-like

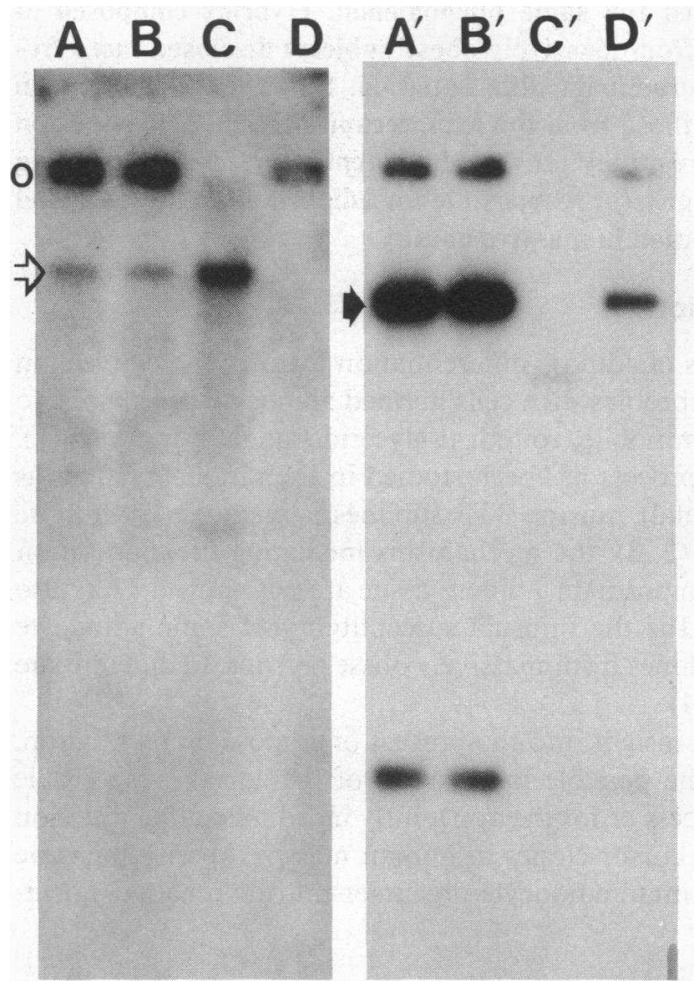

Figure 1. Autoradiograms of Eco RI DNA fragments separated by agarose electrophoresis displaying molecular hybridization with probes specific for human and murine DNA. The open arrow points to hybridization bands with the human $\left[{ }^{32} \mathrm{P}\right] \mathrm{DNA}$ probe, phMF-1, for DNA of fusion products composed of adipocyte precursors from the massively obese $(A)$, those comprised of the lean $(B)$, and DNA of unfused precursors from the obese $(C)$; corresponding hybridization did not occur with DNA of murine RAG cells $(D)$. The solid arrow points to hybridization bands with the murine DNA probe, pmMt, for both types of fusion products $\left(A^{\prime} B^{\prime}\right)$ and for RAG cells $\left(D^{\prime}\right)$; corresponding hybridization did not occur with precursors from massively obese subjects $\left(C^{\prime}\right)$. $O$ designates the origin. 

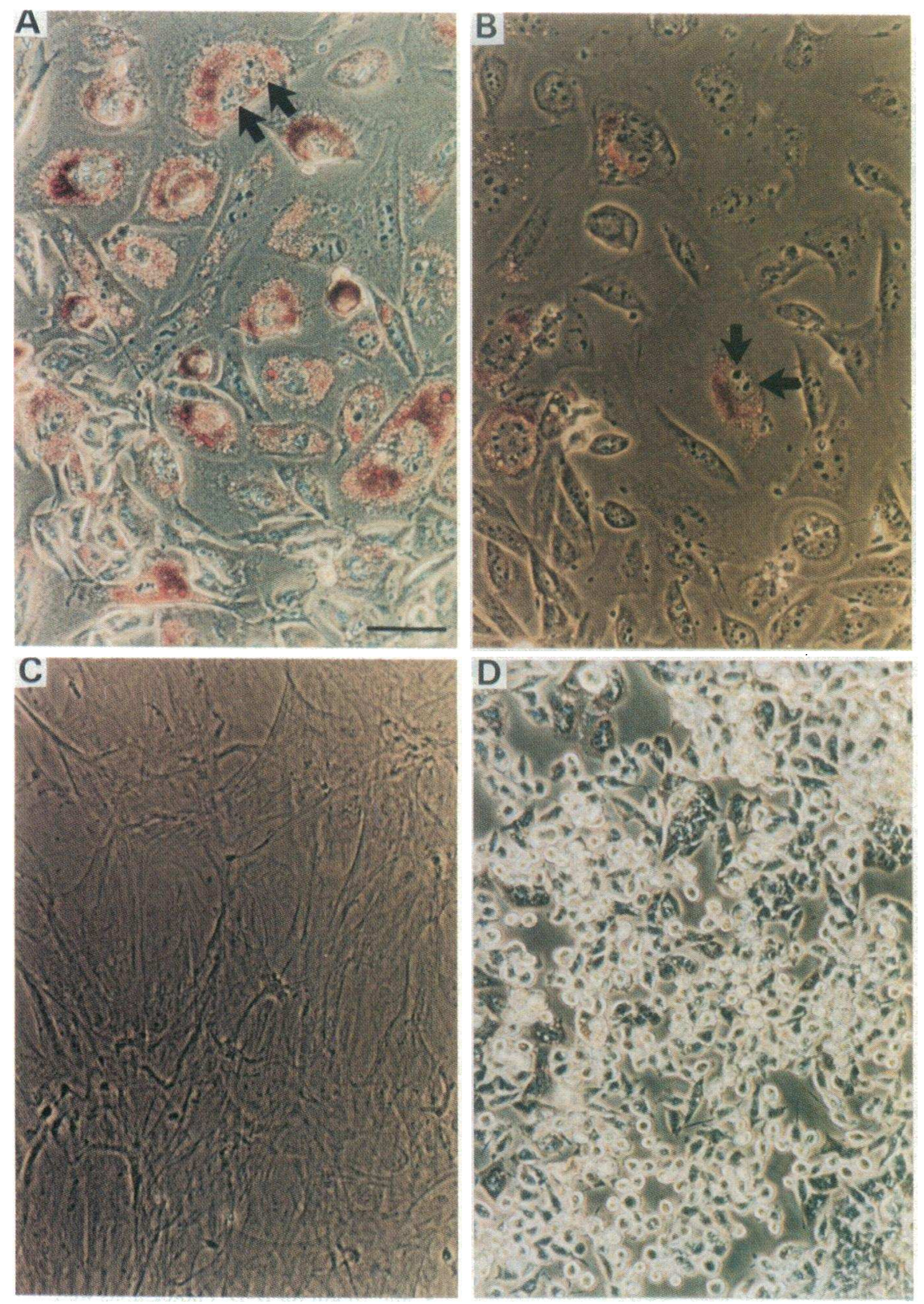

Figure 2. Morphology of cell hybrids and of parental cells. The human omental adipocyte precursor-murine renal (RAG) hybrids composed of precursors from massively obese persons $(A)$ revealed appreciably greater triglyceride accumulation, as indicated by Oil-Red-O staining, than hybrids comprised of precursors from the lean $(B)$. A much greater number of hybrids composed of precursors from the obese revealed cell rounding and triglyceride deposition $(A)$, as compared to those in $B$. The double arrows point to the two nuclei of the heterocaryons, which also accumulated triglyceride $(A, B)$. Under the particular culture conditions, neither precursor-precursor fusion products nor unfused adipocyte precursors from the massively obese $(C)$, nor RAG cells $(D)$ disclosed lipid accumulation by Oil-Red-O staining. The black bar designates $20 \mu \mathrm{m}$. Photographs were taken at $\times 200$. cells also deficient in neutral lipid (Fig. $2 A, B$ ). In the case of the hybrids composed of precursors from all four massively obese persons (Fig. $2 A$ ), $\sim 10 \%$ accumulated lipid. In contrast, appreciable Oil-Red-O staining was present in only $2-5 \%$ of all hybrids composed of precursors from three lean subjects (Fig. 2 B). Not only were homocaryons capable of triglyceride accretion, but fused cells containing two interspecific nuclei (heterocaryons) revealed similar degrees of accretion, as illustrated by arrows to the nuclei of such cells in Fig. $2 A, B$. Under the culture conditions used for these studies, (unfused) adipocyte precursors do not differentiate. Moreover, neither precursor-precursor fusion products, nor murine RAG cells disclosed lipid deposition (Fig. $2 C, D$ ). In other control studies, HAT medium did not induce differentiation in adipocyte precursors, while ouabain did not exert such influence on RAG cells.
Under conditions that induce adipose differentiation (addition of methylisobutylxanthine-dexamethasone followed by insulin) (16), the frequency of hybrids accruing triglyceride and the degree of accumulation increased considerably, even in those composed of precursors from lean subjects (Fig. $3 \mathrm{~A}$ ). As mentioned, neutral lipid accumulation revealed by OilRed-O is a reliable indicator of triglyceride accretion and adipose differentiation in these circumstances (11). Addition of methylisobutylxanthine-dexamethasone-insulin did not result in lipid accumulation or change in shape of RAG cells. Another important control involved fusion of human skin fibroblasts (CRL 1221) and murine renal (RAG) cells; when these mesenchymal cells, which do not accrue triglyceride in vivo, were partners in the hybrids, lipid deposition was not observed. 

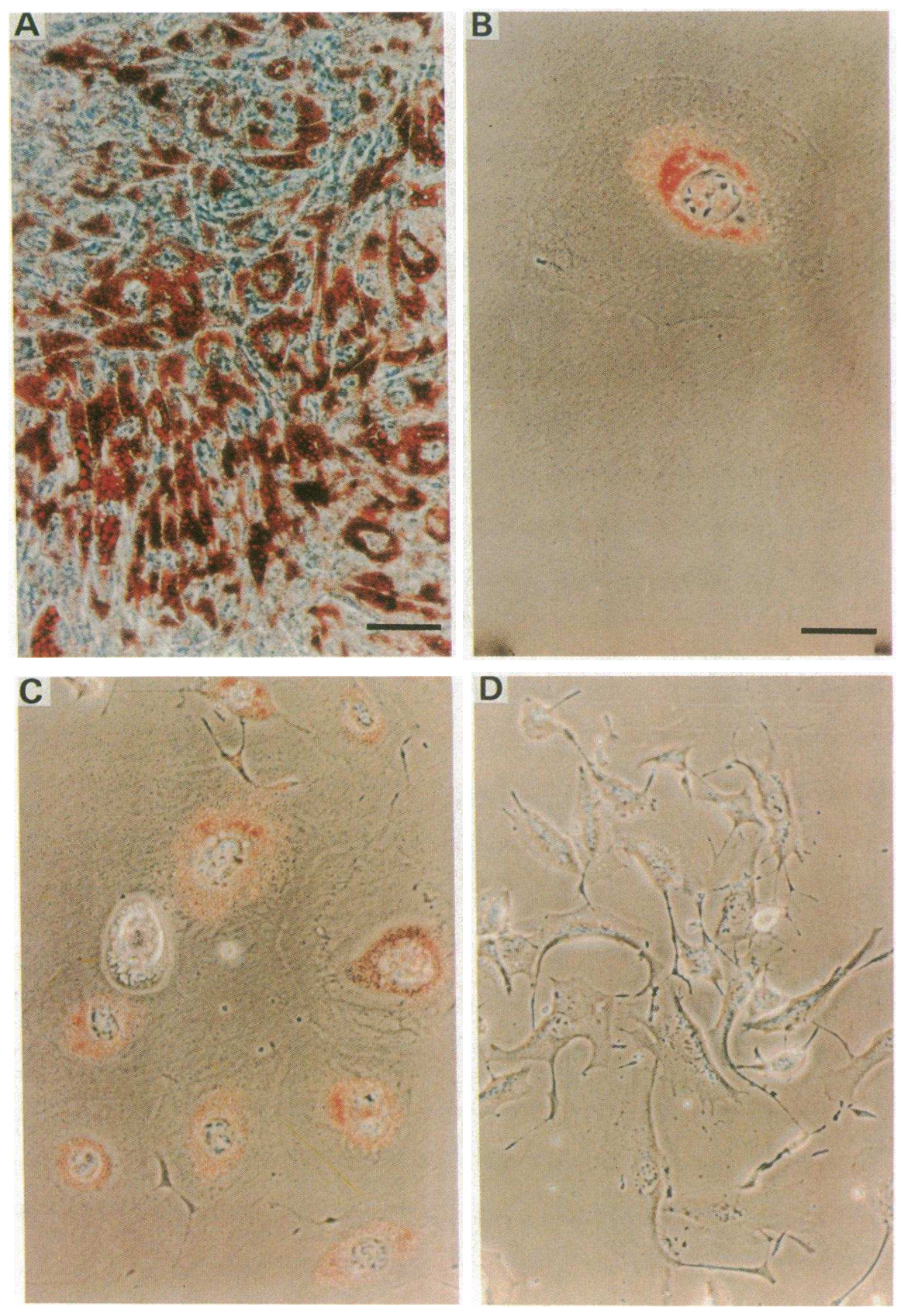

Figure 3. Human adipocyte precursor-murine RAG hybrids. Treatment with methylisobutylxanthine-dexamethasone followed by insulin resulted in greater frequency and degree of triglyceride accumulation, as indicated by Oil-Red-O, even in precursors composed of cells from lean subjects $(A)$. Some clones of hybrid cells made up of precursors from either massively obese $(B)$ or lean persons, initially fibroblast-like, became round and accumulated appreciable triglyceride. Upon subculture (second passage after fusion in this case), hybrids comprised of cells from the massively obese, revealed renewed cell rounding and lipid accretion $(C)$, in contrast to the maintenance of the fibroblast-like characteristics of hybrids composed of precursors from lean persons $(D)$. The bar designates $40 \mu \mathrm{m}$ in $A$, and $20 \mu \mathrm{m}$ for $B-D$. Photographs were taken at $\times 100(A)$ and $\times 200(B-D)$.
Cell cloning further demonstrated the different morphological features of the hybrid cells. As anticipated, the rounded hybrids did not replicate. The fibroblast-like fusion products multiplied, and a portion became round and accumulated triglyceride (Fig. 3 B). Hybrid clones composed of precursors from massively obese subjects displayed this phenomenon in greater frequency and degree, as noted for the mixed hybrid cell populations. More specifically, 30 hybrid cell clones were isolated, all composed of preadipocytes from massively obese subjects. Of these clones, 5 revealed rounding and triglyceride accretion, 16 exhibited only rounding, while 9 clones displayed fibroblast-like appearance and were deficient in lipid. Upon at least the subsequent two subcultures, the majority of the cell hybrids in each of the clones revealed renewed expres- sion of their initial morphology. For example, the first group of clones retained the capability of both rotundation and triglyceride deposition.

Up to ten subcultures (a total of about 45 divisions), $\sim 10 \%$ of the cells in the mixed hybrid cell population composed of precursors from the massively obese, retain the capacity to become round and accumulate triglyceride, as exemplified by Fig. $3 C$, which shows cells in the second subculture. In contrast, hybrids made up of cells from lean persons, lose the ability to accrue triglyceride after division or subculture (Fig. $3 D$ ).

Glyceride-glycerol determination. As indicated in Table I, chemical determination of glyceride-glycerol confirmed that the material staining with Oil-Red-O was predominantly tri- 
Table I. Glyceride-Glycerol Content

\begin{tabular}{lc}
\hline \multicolumn{1}{c}{ Cells from which extract derived } & Glyceride-glycerol \\
\hline & $\mu \mathrm{g} / \mathrm{mg}$ protein \\
Human adipocyte precursors from massively obese & \\
subjects & $0.2^{*}$ \\
Hybrid cells (not cloned) & 5.0 \\
Hybrid cells (not cloned) & 2.2 \\
$\begin{array}{l}\text { Hybrid clones accumulating Oil-Red-O staining } \\
\text { material }\end{array}$ & 3.5 \\
Hybrid clones with fibroblast-like characteristics & \\
\hline
\end{tabular}

* Each value represents the mean of two determinations.

${ }^{\ddagger}$ Hybrid cells composed of precursors from massively obese subjects + murine RAG cells.

${ }^{5}$ Hybrid cells composed of precursors from lean subjects + murine RAG cells.

glyceride. The greater accumulation in hybrids composed of adipocyte precursors from massively obese subjects, and in some of the clones of these hybrids, supports the greater propensity for triglyceride accretion, as compared to hybrids composed of cells from the lean.

Glycerophosphate dehydrogenase activity. To ascertain that triglyceride accretion reflected adipose differentiation, cytosolic glycerophosphate dehydrogenase activity, an excellent marker of this process, was determined. As presented in Table II, the specific activity of this enzyme in the cell-free fractions from hybrids composed of precursors from the massively obese $(39.1 \pm 2.5 \mathrm{U} / \mathrm{mg}$, mean $\pm \mathrm{SE})$ and of precursors from the lean (29.2 \pm 0.5$)$, was significantly higher than that of preadi-

Table II. Cytosolic Glycerophosphate Dehydrogenase Activity

\begin{tabular}{lcc}
\hline Cells from which extract derived & Specific activity* & $\begin{array}{c}\text { \% Activity after } \\
\text { heating at } \\
50^{\circ} \mathrm{C} \text { for } 2.5 \\
\text { min }\end{array}$ \\
\hline $\begin{array}{l}\text { Human adipocyte precursors from } \\
\text { massively obese subjects }\end{array}$ & $1.2 \pm 0.3^{\ddagger}$ & - \\
$\begin{array}{l}\text { Hybrids composed of precursors } \\
\text { from massively obese subjects } \\
+ \text { murine RAG cells }\end{array}$ & $39.1 \pm 2.5^{\ddagger 8}$ & 42.0 \\
$\begin{array}{l}\text { Human adipocyte precursors from } \\
\text { lean subjects }\end{array}$ & $1.0 \pm 0.4^{\ddagger}$ & - \\
$\begin{array}{l}\text { Hybrids composed of precursors } \\
\text { from lean subjects }+ \text { murine } \\
\text { RAG cells }\end{array}$ & & 14.6 \\
\hline
\end{tabular}

* $1 \mathrm{U}$ of activity is defined as the dihydroxyacetone phosphate-dependent oxidation of $1 \mathrm{nmol} \mathrm{NADH} \min ^{-1}$ at $27^{\circ} \mathrm{C}$.

${ }^{\ddagger}$ Mean \pm SE. Experiments were conducted with precursors derived from two obese and two lean subjects. Enzyme activity was determined in duplicate or triplicate at three protein levels under linear conditions.

The two values are significantly different by the $t$ test for unpaired samples at $P<0.001$. pocytes (1.2 \pm 0.3 and $1.0 \pm 0.4$, for obese and lean, respectively) grown under similar culture conditions in the absence of inducers or promoters of differentiation. By the $t$ test for unpaired samples, the difference was significant at $P<0.001$. The specific activity for cell hybrids composed of preadipocytes from the massively obese was significantly higher $(P$ $<0.001)$ than that of those comprising cells from the lean. The fact that $42 \%$ of the activity was retained in the hybrids after heating at $50^{\circ} \mathrm{C}$ for $2.5 \mathrm{~min}$ indicated the presence of the "thermostable" isoenzyme of cytosolic glycerophosphate dehydrogenase characteristic of adipose differentiation (18). In contrast, only $6.5 \%$ of the cytosolic glycerophosphate dehydrogenase activity in the RAG cells was retained after heating to $50^{\circ} \mathrm{C}$ for $2.5 \mathrm{~min}$. This finding rules out reversion to the "embryonic thermolabile" isoenzyme that might have resulted from RAG cells, since they originate from a malignant neoplasm.

\section{Discussion}

The results indicate that not only do some human adipocyte precursor-murine (RAG cells) hybrids reveal an unusual propensity to accumulate triglyceride, but those composed of precursors from the massively obese demonstrate this phenomenon to a more enduring and strikingly greater extent than those derived from lean subjects. The precursors from both lean and obese subjects can be induced to differentiate, at least partially, by specific supplements to the culture medium (19). In contrast, the RAG cells or RAG-RAG hybrids, have not disclosed triglyceride accretion or adipose differentiation under any of the conditions tested. Thus, while there must be complementation between precursors and RAG cells, the human cells provide the indispensable factor(s) for triglyceride accumulation. The latter is probably an expression of differentiation in view of the rise in activity of cytosolic, "thermostable" glycerophosphate dehydrogenase (18), and the characteristic cell rounding (1). Since RAG cells are of ectodermal origin, the complementation within the hybrids may be an example of epithelial-mesenchymal interactions, as described for other systems $(20,21)$. We are exploring whether renal factors influence the differentiation of rat renal adipocyte precursors.

Fusion of cells frequently leads to extinction of a differentiated function expressed by only one of the parent cells, e.g., mouse mitochondrial glycerophosphate dehydrogenase (22-24). This phenomenon is unequivocally due in some cases to repression (25). In addition, fusion of malignant with normal cells, e.g., EJ bladder carcinoma cells with human fibroblasts, results in hybrids that are generally not tumorigenic (26). Activation of a gene has been demonstrated in a few instances, particularly when the genes of the differentiated parent were present in increased "dosage" (27-29). Thus, the triglyceride accretion occurring in the precursor-RAG hybrids may be due to either de-repression or direct induction of the genome in human precursors. Other mechanisms responsible for the observed changes may be envisaged. In view of the notable physical and chemical changes in the membrane composition resulting from fusion (30), the plasma membrane may have acquired the ability to bind or transport factors, possibly present in fetal bovine serum, which lead to adipose differentiation. 
Since in addition to syncaryons, heterocaryons revealed similar degrees of triglyceride accumulation, triggering messages from the murine nucleus or other cellular component, may have been transmitted, through the cytoplasm, to the human nucleus. "Cytoplasmic activation" has been described for human amniocyte-differentiated mouse myocyte stable heterocaryons $(28,29)$. The role of cytoplasmic factors in gene expression, both suppression and activation, has already been shown by "cybrids," which are formed by fusing whole cells with cytoplasts $(31,32)$. For example, cybrids from mouse teratocarcinoma stem cells and cytoplasts of rat myoblastic cells revealed various patterns of differentiation (33).

The appreciably greater triglyceride accumulation in the hybrids composed of precursors from massively obese persons, suggests the operation of genetic elements, either specific or in "increased dosage." This proposal is consistent with abundant evidence for heritable factors contributing to the development of obesity, particularly massive corpulence $(34,35)$. In propagating culture of human-murine hybrids, human chromosomes are lost mainly at random (9). Hence, the availability of hybrid cell clones with different characteristics may enable mapping of chromosomes containing genes involved in adipose differentiation. The reasons for the diverse phenotypes isolated in our studies are as yet unknown. These might be secondary to dissimilar events related to the process of fusion itself. Or the disparities could be a reflection of chromosomal loss, generally human in such hybrids. It might thus be conjectured that clones revealing rounding, but no triglyceride accretion, have lost genetic material involved in a hormonal mechanism(s), or enzyme(s), or regulatory factor(s) required for deposition of this lipid. Since cell rounding is a fundamental feature of adipose differentiation, even in the absence of triglyceride accumulation $(1,3)$, clones remaining fibroblastlike may have lost the gene(s) responsible for differentiation or its exaggeration in massive corpulence. After localization, it may become feasible to characterize this gene(s).

\section{Acknowledgments}

Supported by grants from the Canadian (Alberta) Heart Foundation, the Medical Research Council of Canada, and the Alberta Heritage Foundation for Medical Research. Mr. Le Blanc held an AHFMR studentship.

\section{References}

1. Roncari, D. A. K. 1984. Pre-adipose cell replication and differentiation. Trends Biochem. Sci. 9:486-489.

2. Green, H., and O. Kehinde. 1974. Sublines of mouse 3T3 cells that accumulate lipid. Cell. 1:113-116.

3. Green, H. 1978. The adipose conversion of 3T3 cells. In 10th Miami Winter Symposium on Differentiation and Development. F. Ahmad, J. Schultz, T. R. Russell, and R. Werner, editors. Academic Press, New York. 13-33.

4. Roncari, D. A. K., D. C. W. Lau, P. Djian, S. Kindler, and D. K. Yip. 1983. Culture and cloning of adipocyte precursors from lean and obese subjects: Effects of growth factors. In The Adipocyte and Obesity: Cellular and Molecular Mechanisms. A. Angel, C. H. Hollenberg, and D. A. K. Roncari, editors. Raven Press, New York. 65-73.

5. Van, R. L. R., C. E. Bayliss, and D. A. K. Roncari. 1976. Cytological and enzymological characterization of adult human adipocyte precursors in culture. J. Clin. Invest. 58:699-704.
6. Roncari, D. A. K., S. Kindler, and C. H. Hollenberg. 1986. Excessive proliferation in culture of reverted adipocytes from massively obese persons. Metab. Clin. Exp. 35:1-4.

7. Leong, M. M. L., and C. C. Lin. 1980. Production of interspecific somatic cell hybrids using polyethylene glycol. J. Tissue Cult. Methods. 6:79-83.

8. Davidson, R. L., K. A. O'Malley, and T. B. Wheeler. 1976. Polyethylene glycol-induced mammalian cell hybridization. Effect of polyethylene glycol molecular weight and concentration. Som. Cell Genet. 2:271-280.

9. Tunnacliffe, A., F. Benham, and P. Goodfellow. 1984. Mapping the human genome by somatic cell genetics. Trends Biochem. Sci. 9:5-7.

10. Thompson, L. H., and R. M. Baker. 1973. Isolation of mutants in cultured mammalian cells. In Methods of Cell Physiology. D. M. Prescott, editor. Academic Press, New York. 209-281.

11. Green, H., and O. Kehinde. 1975. An established preadipose cell line and its differentiation in culture. II. Factors affecting the adipose conversion. Cell. 5:19-27.

12. Hoar, D. I., D. B. Haslam, and D. M. Starozik. 1984. Improved direct molecular diagnosis and rapid fetal sexing. Prenat. Diagn. 4:241-247.

13. Tynan, K., and D. I. Hoar. 1986. A human low copy repetitive probe (hMF \#1) and its potential for estimating genetic and evolutionary distance. 7th International Congress of Human Genetics. (Abstract MV.3).

14. Feinberg, A. P., and B. Vogelstein. 1983. A technique for radiolabelling DNA restriction endonuclease fragments to high specific activity. Anal. Biochem. 132:6-13.

15. Feinberg, A. P., and B. Vogelstein. 1984. Addendum. A technique for radiolabelling DNA restriction endonuclease fragments to high specific activity. Anal. Biochem. 137:266-267.

16. Russell, T. R. 1981. Growth and cytodifferentiation of 3T3-L1 preadipocytes into adipocytes. Methods Enzymol. 72:720-723.

17. Eggstein, M., and E. Kuhlmann. 1974. In Methods of Enzyme Analysis. 2nd ed. Vol 4. H. U. Bergmeyer, editor. Verlag Chemie, Weinheim/Academic Press, Inc., New York and London. 1825-1831.

18. Wise, L. S., and H. Green. 1979. Participation of one isozyme of cytosolic glycerophosphate dehydrogenase in the adipose conversion of 3T3 cells. J. Biol. Chem. 254:273-275.

19. Van, R. L. R., and D. A. K. Roncari. 1978. Complete differentiation of adipocyte precursors. A culture system for studying the cellular nature of adipose tissue. Cell Tissue Res. 195:317-329.

20. Rutter, W. J., R. L. Pictet, and P. W. Morris. 1973. Toward molecular mechanisms of developmental processes. Annu. Rev. Biochem. 42:601-646.

21. Cunha, G. R., A. A. Donjacour, and Y. Sugimura. 1986. Stromal-epithelial interactions and heterogeneity of proliferative activity within the prostate. Biochem. Cell Biol. 64:608-614.

22. Davidson, R. L., and P. Benda. 1970. Regulation of specific functions of glial cells in somatic hybrids. II. Control of inducibility of glycerol-3-phosphate dehydrogenase. Proc. Natl. Acad. Sci. USA. 67:1870-1877.

23. Mevel-Ninio, M., and M. C. Weiss. 1981. Immunofluorescence analysis of the time-course of extinction, reexpression, and activation of albumin production in rat hepatoma-mouse fibroblast heterocaryons and hybrids. J. Cell Biol. 90:339-350.

24. Edwards, Y., S. L. McMillan, C. Kielty, and M.-A. Shaw. 1985. The expression of human glycerol-3-phosphate dehydrogenase in human/rodent somatic-cell hybrids. Biochem. Genet. 23:405-422.

25. Weiss, M. C., and M. Chaplain. 1971. Expression of differentiated functions in hepatoma cell hybrids: reappearance of tyrosine aminotransferase inducibility after the loss of chromosomes. Proc. Natl. Acad. Sci. USA. 68:3026-3030.

26. Geiser, A. G., C. J. Der, C. J. Marshall, and E. J. Stanbridge. 1986. Suppression of tumorigenicity with continued expression of the 
c-HA-ras oncogene in EJ bladder carcinoma-human fibroblast hybrid cells. Proc. Natl. Acad. Sci. USA. 83:5209-5213.

27. Brown, J. E., and M. C. Weiss. 1975. Activation of production of mouse liver enzymes in rat hepatoma-mouse lymphoid cell hybrids. Cell. 6:481-494.

28. Blau, H. M., C-P. Chiu, and C. Webster. 1983. Cytoplasmic activation of human nuclear genes in stable heterocaryons. Cell. 32:1171-1180.

29. Pavlath, G. K., and H. M. Blau. 1986. Expression of muscle genes in heterokaryons depends on gene dosage. J. Cell Biol. 102:124130.

30. Verkleiji, A. J., J. Leunissen-Bijvelt, B. de Kruijiff, M. Hope, and P. R. Cullis. 1984. Non-bilayer structures in membrane fusion. In Cell Fusion. Ciba Foundation Symposium 103. D. Evered, and J. Whelan, editors. Pitman, London. 45-54.

31. Gopalakrishnan, T. V., E. B. Thompson, and W. F. Anderson. 1977. Extinction of hemoglobin inducibility in Friend erythroleuke- mia cells by fusion with cytoplasm of enucleated mouse neuroblastoma or fibroblast cells. Proc. Natl. Acad. Sci. USA. 74:1642-1646.

32. Gopalakrishnan, T. V., and W. F. Anderson. 1979. Epigenetic activation of phenylalanine hydroxylase in mouse erythroleukemia cells by the cytoblast of rat hepatoma cells. Proc. Natl. Acad. Sci. USA. 76:3932-3936.

33. Iwakura, Y., M. Nozaki, M. Asano, M. C. Yoshida, Y. Tsukada, N. Hibi, A. Ochiai, E. Tahara, M. Tosu, and T. Sekiguchi. 1985. Pleiotropic phenotypic expression in cybrids derived from mouse teratocarcinoma cells fused with rat myoblast cytoblasts. Cell. 43:777-791.

34. Roncari, D. A. K. 1986. Obesity and lipid metabolism. In Clinical Medicine. Vol. 9. J. A. Spittell, Jr., and R. Volpé, editors. Harper and Row, New York. 1-57.

35. Lau, D. C. W., D. A. K. Roncari, and C. H. Hollenberg. 1987. Release of mitogenic factors by cultured preadipocytes from massively obese human subjects. J. Clin. Invest. 79:632-636. 